UDC 351.74

DOI: $10.31733 / 2078-3566-2019-5-46-50$

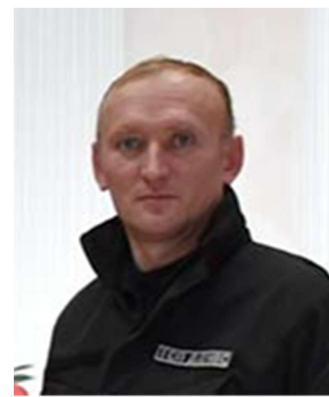

Vasyl

POLYVANIUK ${ }^{\circledR}$

Ph.D, Ass. Prof.

$\begin{array}{r}\text { Valerii }^{\text {BILICHENKO }^{\odot}} \\ \hline\end{array}$

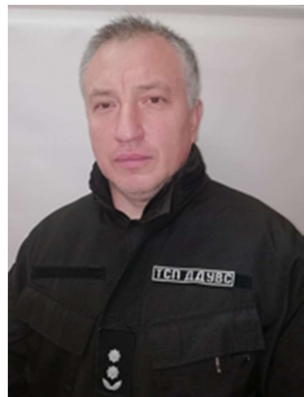

(Dnipropetrovsk State University of Internal Affairs)

\title{
CURRENT METHODS OF PUBLIC SECURITY DURING THE PROTECTION OF PUBLIC ORDER: BASIC ASPECTS
}

Василь Поливанюк, Валерій Біліченко. СУЧАСНІ МЕТОДИ ЗАБЕЗПЕЧЕННЯ ПУБЛІЧНОЇ БЕЗПЕКИ ПІД ЧАС ОХОРОНИ ГРОМАДСЬКОГО ПОРЯДКУ: ОСНОВНІ АСПЕКТИ. Досліджено механізм забезпечення публічного порядку і безпеки у сучасних умовах, зокрема створення інноваційних інструментів i прийомів протидії порушення порядку, встановленого законом. Здійснено характеристику основного методу профайлінг та встановлено основні положення щодо застосування такого. Досліджено питання застосування спеціальних засобів: електрошокерів та вогнепальної зброї. Наголошено на необхідності впровадження профійлінга у практичну дільність МВС України.

Досліджено питання використання прийомів та інструментів, які активно використовуються для забезпечення громадського порядку. Комплекс заходів щодо особистої безпеки характеризується необхідністю володіти поліцейськими навичками, спеціальними знаннями та навичками поводження 3 великою кількістю людей та за наявності численних провокацій, а також можливих терористичних проявів при забезпеченні громадської безпеки. Профайлінг - це прогресивний метод забезпечення громадської безпеки та порядку, який використовується в контексті боротьби з терористичними актами, це сукупність психологічних методів і методик оцінки та прогнозування поведінки людини на основі аналізу найбільш інформативних приватних ознак, характеристик зовнішності, невербального і вербального поведінки.

Поєднання теоретичного навчання профілювання та практичного досвіду співробітників MBC України та інших правоохоронних органів може стати серйозною зброєю у боротьбі 3 тероризмом. Ефективність застосування технології профілювання багато в чому залежатиме від рівня підготовки та професійного досвіду працівника. Крім того, досить актуальним $\epsilon$ питання застосування нового в сучасній системі боротьби зі злочинністю спеціального інструменту пристрою оглушення. Однак багато питань виникають у зв'язку з використанням поліцією вогнепальної зброї на підставі закону. На жаль, механізм гарантування прав та свобод правоохоронця на сьогодні остаточно не $є$ врегульованим.

Ключові слова: особиста безпека, публічний порядок, публічна безпека, терористичні прояви, тероризм, профайлінг, електрочокер, спеціальні засоби, заходи примусу.

Problem statement. Today, the issue of ensuring personal security while protecting public order is irrelevant in the activities of the National Police of Ukraine, regardless of the official situation of the police officer. It is important to have basic professional skills in order to ensure personal safety and to prevent the possible negative consequences that may result from negligent compliance with the elementary rules of professional discipline. In addition, it is impossible to overlook the use of techniques and tools that are actively used today to ensure public order.

Analysis of publications that started solving this issue. The topic of ensuring public order and security in modern conditions is covered by national scientists in the context of the

(C) Polyvaniuk V., 2019

ORCID iD: https://orcid.org/0000-0003-3295-4434

k_tsp@dduvs.in.ua

(C) Bilichenko V., 2019

k_tsp@dduvs.in.ua 
information component, as well as methods of security (V. Konakh, Y. Maksimenko), the development of international cooperation in this field (Y. Romanchuk), the role in the context of European integration (Dubov) and the fight against terrorism (I. Alekseenko, D. Kislov), mechanisms of implementation in a particular region (V. Kozubsky) or in the media space (G. Sashchuk).

Basic content. In the field of regulatory support of the National Police of Ukraine, a number of legal acts have been created in order to coordinate the actions of police officers in the performance of their duties. In addition, the regulatory framework provides for the legitimate use of physical force, special weapons and firearms, which can also be considered as a form of providing police with their own security against further harmful consequences that may arise from the unlawful use of coercive measures provided for by current legislation, which may exceed the full .

Personal security is a system of organizational, legal, physical and tacticalpsychological measures that allow to preserve the life and health of an employee of the National Police of Ukraine and maintain a high level of effectiveness of his professional actions [1].

Rather, personal safety can be considered as a result of compliance and enforcement, as well as a set of measures aimed at reducing the level of occupational risk to the minimum possible, which allows:

- to guarantee the preservation of life and health, that is, the creation of a subjective opportunity for the police to be able to navigate a difficult professional situation and, as a consequence, not be adversely affected;

- to guarantee the normal mental state of the employee, because the ability to act correctly and consistently in a critical situation allows you to maintain mental balance and confidence in their actions;

- to guarantee the police officer's ability to deal with professional issues with high efficiency, which allows him to solve complex professional issues in a mobile way.

In addition, it should be noted that personal security as a tactical category is characterized by a certain specificity, ie conditions, content and forms of professional activity, as well as the presence of special measures of organizational, legal, managerial and logistical nature, which are combined with professional and psychological training. Undoubtedly, the police officer, while maintaining public security and order, must have the skills, special knowledge and skills to deal with a large number of people and subject to numerous provocations as well as possible terrorist manifestations, which is a pressing problem in today's globalized society. This problem exists in Ukraine as well.

In today's globalized society, the issue of public security, which is provided by relevant public authorities, mainly executive bodies, with special powers, is particularly acute. In particular, in Ukraine, such a body is the National Police of Ukraine, whose main tasks include ensuring public security and order. To accomplish this task, innovative tools and techniques are created to counteract the violation of the procedure established by law. That is why law enforcement officers, according to the requirements of the time, develop a method of counteracting the attempts of public disorder.

Profiling is a progressive method of ensuring public safety and order that is used in the context of combating terrorist acts. This technique is actively distributed not only in the bodies of the National Police of Ukraine, but also in those services or units that provide public order, external and internal security. The use of profiling technology allows to identify potentially dangerous citizens in the early stages [2, p. 134].

Profiling is a set of psychological methods for assessing and predicting human behavior based on appearance characteristics, analysis of the most informative individual personality traits. $[3$, p. 21]. The main purpose of profiling is to identify potentially dangerous persons, and its basis is the visual diagnosis of a person's psycho-emotional state (observation and special questioning; fixation of psychological behavioral responses to responses - non-verbal and verbal). Profiling uses two main diagnostic methods: the method of psychological observation (to look and find the mismatch) and the method of questioning (to ask and observe the reaction) [4, p. 20].

The concept of profiling is based on the fact that unlawful action and its preparation can be detected by analyzing a certain set of physical, psychological, behavioral traits that characterize suspects from the standpoint of their potential danger. There are indicators that are critical for a person to be at risk, particularly terrorists: demonstrative aggression; covert aggression; excitement; alienation. The emotional state of a person, which is judged by signs of anxiety, fear, excitement and others, is considered in profiling as an additional factor in the analysis of the iden- 
tified dominant signs. There are key signs in non-verbal and verbal human behavior that allow profilers to identify a terrorist in a human stream and to classify it as potentially dangerous.

Today, profiling has been successfully used in a number of airlines for security at airports in European countries as well as in Ukraine. This technology has been used for many years by the Israeli airline El Al, one of the safest in the world. In 1968, it was her staff who developed this method of counter-terrorism. In the US, profiling programs are also in place to search for and accumulate statistics from suspicious behaviors [5]. At the heart of the Israeli concept of profiling is the notion that every passenger can be a terrorist and every item an explosive device. Therefore, all activities undertaken within the framework of this technology are intended to confirm or refute this claim.

Profiles take into account many psychological features of terrorists, adapting them to the specifics of their activities. Further work in this direction should, in our opinion, be directed towards the fusion of theoretical knowledge and practical skills, since profiling is the area of anti-terrorist activity that allows to realize this principle most clearly.

Generally speaking, one of the most important tasks of effective use of profile programs in the system of national and human security is the training of specialists intended for the implementation of these programs. A significant advantage of the profiling technique in its flexibility and versatility, which makes it possible to apply it to both special services and police and military at any mass gathering of people, as well as in the field of public order policing, operational search, counteracting drug trafficking and the like.

Profiling is not the only effective, innovative method used by police officers to ensure public safety. Although not widely used in modern service, it offers excellent prospects for detecting and preventing crimes against public security.

In addition, as noted above, the use of special facilities is an integral part of ensuring police safety. In particular, the use of stun devices to stop a public-order offense.

Today, profiling has been successfully used in a number of airlines for security at airports in European countries as well as in Ukraine. This technology has been used for many years by the Israeli airline $\mathrm{El} \mathrm{Al}$, one of the safest in the world. In 1968, it was her staff who developed this method of counter-terrorism. In the US, profiling programs are also in place to search for and accumulate statistics from suspicious behaviors [5]. At the heart of the Israeli concept of profiling is the notion that every passenger can be a terrorist and every item an explosive device. Therefore, all activities undertaken within the framework of this technology are intended to confirm or refute this claim.

Profiles take into account many psychological features of terrorists, adapting them to the specifics of their activities. Further work in this direction should, in our opinion, be directed towards the fusion of theoretical knowledge and practical skills, since profiling is the area of anti-terrorist activity that allows to realize this principle most clearly.

Generally speaking, one of the most important tasks of effective use of profile programs in the system of national and human security is the training of specialists intended for the implementation of these programs. A significant advantage of the profiling technique in its flexibility and versatility, which makes it possible to apply it to both special services and police and military at any mass gathering of people, as well as in the field of public order policing, operational search, counteracting drug trafficking and the like.

Profiling is not the only effective, innovative method used by police officers to ensure public safety. Although not widely used in modern service, it offers excellent prospects for detecting and preventing crimes against public security.

In addition, as noted above, the use of special facilities is an integral part of ensuring police safety. In particular, the use of stun devices to stop a public-order offense.

Employees of the National Police of Ukraine have the right, in accordance with the law of Ukraine "On the National Police of Ukraine" to use stun devices as a measure of coercion. That is why such application will be quite legal and will not require additional legislative support. In addition, active procurement and implementation of such funds is underway, albeit for a minimal reason. According to Avakov on the active introduction of stun guns in law enforcement activities of the National Police of Ukraine, said in 2016, it should be concluded that stun devices have long had to be widely used by police, that is, from cadets, which is to study their rules, to study their rules safety measures and principles of operation of the device [8].

The most severe and problematic measure of coercion is the use of firearms, so the tactical skills and knowledge of a police officer, as well as his ability to find a solution to a difficult situation, must be perfect. In domestic practice, recently the situation is such that the police, understand- 
ing the consequences, albeit the normatively justified use of firearms, avoid the enforcement and application of this measure of coercion, which sometimes leads to their failure to exercise their powers, the inactivity of their special means, and also causing harm to the lives and health of other citizens, which causes no less condemnation than the use of firearms. Based on this situation, one can ask the question: how to act in such situations to the employee of the National Police of Ukraine and how the mechanism of supervision of cases of use of firearms in the system of the Ministry of Internal Affairs of Ukraine should be improved.

At the legislative level it is stated that the use of firearms is the most severe measure of coercion [6]. This provision is stated in Article 46 of the Law of Ukraine "On the National Police". The use of firearms by police officers always entails certain consequences, the assessment of which depends on the reaction of the public and the authorities. That is why the problem of the implementation of the current legislation at all levels of society, the citizens' awareness of the real ability of police to use firearms to prevent or terminate unlawful acts under the provisions of Article 46 of the above law is quite relevant [6]. Modern domestic society should take into account the principle of lawfulness of police actions and give priority to the realization that the law enforcement officer acts solely within the law.

Conclusion. Ensuring the personal security of a police officer is an important part of his or her professional activity. Today, one of the most important tasks for the education system of employees of the Ministry of Internal Affairs of Ukraine is the organization of training of profiling technology. The effectiveness of the application of profiling technology will largely depend on the level of training and professional experience of the employee. The combination of theoretical profiling training with the practical experience of Ukrainian MIA staff and other law enforcement agencies can become a serious weapon in the fight against terrorism. In addition, the question of the application of a new in the modern system of crime control of a special tool - the stun device - is quite relevant. Many questions arise in connection with the use of firearms by police on the basis of the law, however. Unfortunately, the mechanism of guaranteeing the rights and freedoms of the law enforcement officer is hardly regulated today.

\section{References}

1. Терроризм и организованная преступность: монография. С.А. Солодовников и др. 2-е изд., перераб. и доп. М.: «ЮНИТИ - ДАНА». Закон и право. 2012. 247с.

2. Казанцев С.Я. Терроризм: Борьба. Проблемы противодействия. М. : ГУВШЭ. 2004. 369с.

3. Пирогова Л.К. Актуальность обучения сотрудников ОВД технологии профайлинга как превентивной меры обеспечения безопасности граждан, объектов и территорий. Транспортное право. 2013. №2. С.20-22.

4. Pollack Joshua H., Wood Jason D. Enhancing Public Resilience to Mass-Casualty WMD Terrorism in the United States: Definitions, Challenges, and Recommendations. Defense Threat Reduction Agency, Advanced Systems and Concepts Office, Report Number ASCO 2010 042. Contract Number DTRA01-03-D0010018. URL: https://fas.org/irp/dod/dtra/resilience.pdf

5. Про Національну поліцію України : Закон України від 02.07.2018 №580-VIII. URL: http://zakon.rada.gov.ua/laws/show/580-19.

6. Володіння електрошокером та його використання: правові аспекти. URL:https://3222.ua/article/volodnnya_elektroshokerom_ta_yogo_vikoristannya_pravov_aspekti.html.

7. «Нацполіція починає закупівлю електрошокерів», - Аваков. URL: https://www.rbc.ua/ukr/news/natspolitsiya-nachinaet-zakupku-elektroshokerov-1474893772.html.

Received to editorial office 03.12.2019

1. Terrorizm i organizovannaya prestupnost' [Terrorism and organized crime]: monografíya. S.A. Solodovnikov i dr. 2-ye izd., pererab. i dop. M.: «YUNITI - DANA». Zakon i pravo. 2012. 247s. [in Russ.]

2. Kazantsev, S. Ya. (2004) Terrorizm: Bor'ba. Problemy protivodeystviya [Terrorism: The Fight. Counteraction problems]. M. : GUVSHE.. 369 s. [in Russ.]

3. Pirogova, L. K. (2013) Aktual'nost' obucheniya sotrudnikov OVD tekhnologii profaylinga kak preventivnoy mery obespecheniya bezopasnosti grazhdan, ob"yektov i territoriy. Transportnoye pravo. №2. S.20-22. [in Russ.]

4. Pollack Joshua H., Wood Jason D. Enhancing Public Resilience to Mass-Casualty WMD Terrorism in the United States: Definitions, Challenges, and Recommendations. Defense Threat Reduction Agency, Advanced Systems and Concepts Office, Report Number ASCO 2010 042. Contract Number DTRA01-03-D0010018. URL:https://fas.org/irp/dod/dtra/resilience.pdf. [in Eng.]

5. Pro Natsíonal'nu polítsíyu Ukrayíny : Zakon Ukrayỉny víd 02.07.2018 №580-VIII. URL: http://zakon.rada.gov.ua/laws/show/580-19. [in Ukr.]

6. Volodínnya elektroshokerom ta yogo viykorystannya: pravoví aspekty. URL:https://3222.ua/article/volodnnya_elektroshokerom_ta_yogo_vikoristannya_pravov_aspekti.html. [in Ukr.]

7. «Natspolítsíya pochinayê zakupívlyu elektroshokerív», - Avakov. URL: https://www.rbc.ua/ukr/news/natspolitsiya-nachinaet-zakupku-elektroshokerov-1474893772.html. [in Ukr.] 
Summary

The article deals with the use of techniques and tools that are actively used today to ensure public order. The set of measures for personal security is characterized, characterized by the need to possess police skills, special knowledge and skills in dealing with a large number of people and in the presence of numerous provocations, as well as possible terrorist manifestations while ensuring public security. To accomplish this task, innovative tools and techniques are created to counteract the violation of the procedure established by law. That is why law enforcement officers, according to the requirements of the time, develop a method of counteracting the attempts of public disorder. Profiling is a progressive method of ensuring public safety and order that is used in the context of combating terrorist acts. The main purpose of profiling is to identify potentially dangerous persons, and its basis is the visual diagnosis of the psycho-emotional state of the person (observation and special survey; fixation). The most severe and problematic measure of coercion is the use of firearms, so tactical skills and knowledge of the field The use of firearms by police officers always entails certain consequences, the assessment of which depends on the reaction of the public and the authorities.

The combination of theoretical profiling training with the practical experience of Ukrainian MIA staff and other law enforcement agencies can become a serious weapon in the fight against terrorism.

Keywords: personal security, public order, public security, terrorist acts, terrorism, profiling, stun gun, special means, coercive measures.

UDC 351.7

DOI: $10.31733 / 2078-3566-2019-5-50-53$

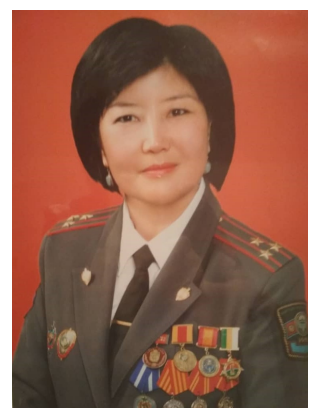

Nazgul SHARSHENOVA ${ }^{(0)}$

Ph.D

(Academy of the Ministry of Internal Affairs

of the Kyrgyz Republic)

\section{SECURITY ISSUES OF THE KYRGYZ REPUBLIC: POLITICAL AND LEGAL ASPECTS}

НазгУЛЬ Шаршенова. ПРОБЛЕМЫ ОБЕСПЕЧЕНИЯ БЕЗОПАСНОСТИ КЫРГЫЗСКОЙ РЕСПУБЛИКИ: ПОЛИТИКО-ПРАВОВЫЕ АСПЕКТЫ. РассмотренЫ теоретические аспекты обеспечения национальной безопасности, на основе анализа которых уточняется определение данного понятия. К проблемам, требующим повышенного внимания, в последнее десятилетие прошлого и настоящего века отнесены неравномерное экономическое развитие регионов, истощение природных ресурсов и разрушение окружающей среды, нелегальная миграция, этнические и религиозные конфликты, транснациональная организованная преступность и международный терроризм. Иначе говоря, произошел переход от «жестких», милитаристских вызовов безопасности к «мягким», носящим преимущественно гуманитарный характер, «выплескивающимся» за пределы государства. Для полноты картины необходимо указать на эволюцию «мягких» угроз безопасности. В начале 1990-х годов на первом месте по значимости находились экологические и природоохранные проблемы, наряду с нелегальной миграцией. К началу 2000-х годов акцент все более смещается на такие вызовы мировой безопасности, как транснациональная организованная преступность и международный терроризм. Прямым подтверждением тому служит повсеместный рост проявлений насилия в виде терроризма, имеющего одним из источников усиливающееся экономическое и социальное неравенство. Не менее актуальным остается и вопрос о будущем международных отношений как исходной точки в формировании системы международной безопасности. Дискуссии характеризовались разноречивым видением ее будущего, положив начало продолжительному обсуждению данной проблематики.

Ключевые слова: национальная безопасность; угроза информационной безопасности; обеспечение информационной безопасности; цель; задачи и субъекты обеспечения политических механизмов в обеспечении безопасности; выявление и противодействие угрозе начиональной безопасности.

Problem statement. Recent achievements of science and technology have led to rapid changes in social, economic and political processes due to information and technologies spheres development. At the same time, information technology is becoming one of the main factors affecting the lives of people, societies and even whole countries. Information society was formed

(C) Sharshenova N., 2019

sharshenova73@mail.ru 